\title{
Association between rump score and course of parturition in cows
}

\author{
Anna Sawa, Mariusz Bogucki, Sylwia Krężel-Czopek and Wojciech Neja \\ University of Technology and Life Sciences in Bydgoszcz, Faculty of Animal Breeding and Biology, Department of Cattle \\ Breeding, Bydgoszcz, Poland
}

\begin{abstract}
Analysis was made of the effect of rump angle and rump width, assessed using a 9-point scoring system, on the course of parturition in cows representing the active population in Pomorze and Kujawy regions of Poland. GLM and FREQ procedures of the SAS package (SAS Institute Inc., Cary, NC, USA) were used in the statistical calculations. The most frequent score for rump angle was 5 ( $44 \%$ of all scores) and that for rump width was 6 ( $30 \%$ of all scores). Human intervention was required for $7 \%$ of calvings, of which dystocia (surgical treatment, injury to the cow or calf, embryotomy) occurred in $0.19 \%$ and caesarean section was performed in $0.11 \%$ of the cases. The course of parturition was affected to a greater extent by rump angle $(P<0.01)$ than by rump width. The largest proportion of difficult parturitions (over $8 \%$ ) was noted when the calvers received rump angle scores of 1-2 or 8-9 points, while raised rump (1-2 points) increased the proportion of dystocia and caesarean sections. The average scores for rump angle in the case of unassisted and easy calvings were 4.95 and 5.02 points, respectively (corresponding to the most desirable, slightly sloping rump) and 4.6 points in the case of dystocia and caesarean sections. A much higher proportion of difficult parturitions and dystocia was also found in cows with a too narrow rump scored with 1-2 points and in those with a wide rump (8-9 points.).
\end{abstract}

Keywords: cows, course of parturition, rump angle, rump width

Abbreviations: FREQ: frequency; GLM: general linear model

Archiv Tierzucht 56 (2013) 81, 816-822

doi: 10.7482/0003-9438-56-081

Corresponding author:

Anna Sawa; email: sawa@utp.edu.pl

Department of Cattle Breeding, Faculty of Animal Breeding and Biology, University of Technology and Life Sciences in Bydgoszcz, Mazowiecka 28, 85-084 Bydgoszcz, Poland
Received: 7 August 2012

Accepted: 16 Juli 2013

Online: 12 August 2013

() 2013 by the authors; licensee Leibniz Institute for Farm Animal Biology (FBN), Dummerstorf, Germany. This is an Open Access article distributed under the terms and conditions of the Creative Commons Attribution 3.0 License (http://creativecommons.org/licenses/by/3.0/). 


\section{Introduction}

The course of parturition is an important functional trait that can determine success in cattle breeding. Difficult births result in high calf mortality, reduced fertility and milk yield, high culling rate of cows and high veterinary costs (Dematawena \& Berger 1997, Patterson \& Herring 1997). Otwinowska-Mindur \& Żarnecki (2005) report that the frequency of difficult and very difficult births in Holstein-Friesian populations varies and usually ranges from 1.5 to $5 \%$; according to the same authors, the frequency of difficult births increased in countries where the proportion of Holstein-Friesian genes in Black-and-White populations increased.

Some of the factors which have been reported to influence the course of calving include rump conformation traits: its length and width (Brzozowski \& Kaczmarek 1988, OtwinowskaMindur \& Żarnecki 2005), pelvic size and rump angle (Nogalski 2004, 2005), pelvic measurements, as well as pelvic area and pelvic volume calculated on their basis (Wójcik 2006). In terms of calving ease, the rump should be slightly sloping (De Jong 1991, Wójcik \& Czaja 2003) as well as long and broad (Ali et al. 1984, Gaines et al. 1993, Hoffman 1997, Murray et al. 2002, Sieber et al. 1989, Thomson \& Wiltbank 1983). The standard for the HolsteinFriesian cow specifies that the rump should be slightly sloping towards the back, long, broad and flat muscled, with muscle profiles slightly concave (especially those of thigh) and tail head low (www.pfhb.pl/programy/Program_hodowlany_PHF_PFHB.pdf).

The conformation assessment system used in Poland is based on the German and Dutch systems. Rump angle and rump width are accounted for when assessing the type and conformation of dairy breed first-calf heifers sired by test bulls and their contemporaries, with scores ranging from 1 to 9 points (Rules for type and conformation assessment of dairy cattle 2004).

The aim of the study was to analyse the relationship between the scores for rump angle and rump width and the course of parturition, based on extensive performance records collected for cows (about $10 \%$ of the Polish population of performance-recorded cows).

\section{Material and methods}

The study used records from the SYMLEK system database concerning the course of 13364 parturition and rump conformation scores of 5193 Polish Holstein-Friesian cows. The animals first calved in 2006-2007 and were used or culled at the end of 2011.

Rump angle is assessed based on the line connecting coxal tubers and ischial tuberosities (popularly known as slope from rump to the floor). Slightly sloping rump is the most desirable (ischial tuberosities slightly below coxal tubers, $3 \mathrm{~cm}$ slope, score of 5 points), while raised (1 point) and sloping rumps ( 9 points) are the least desirable. Rump width is assessed from the distance between ischial tuberosities (narrow :1 point, broad: 9 points, optimum score: 6 points) (Rules for type and conformation assessment of dairy cattle 2004).

Because the scores of 1 and 9 for rump angle and rump width were only sporadic, in further statistical calculations they were added to the scores of 2 and 8 , respectively.

The course of parturition was classified according to SYMLEK as:

- unassisted birth (natural, without human assistance)

- easy calving 
- difficult birth (requiring much more force than normal)

- dystocia (surgical treatment, injury to the cow or calf, embryotomy)

- caesarean section.

Analysis of variance was used to estimate the average score for rump angle and rump width depending on the course of parturition. Significant differences were analysed with the Scheffe test. The chi-square test of independence was used to analyse (SAS 2011):

- frequency of different courses of parturition depending on the score $(1-2,3,4,5,6,7,8-9)$ for rump angle,

- frequency of different courses of parturition depending on the score $(1-2,3,4,5,6,7,8-9)$ for rump width.

\section{Results and discussion}

Like in the study of Guliński (1998), the most frequent scores were 5 for rump angle (44\% of all scores) and 6 for rump width (30\% of all scores) (Table 1). The occurrence of animals characterized by incorrect rump angle (ischial tuberosities higher than or at the same level with coxal tubers of pelvic bone) may be due to the aesthetic preferences of breeders, because calves with a straight rump and cows with wide and high udders are more appealing.

Table 1

Number and percentage of scores for rump angle and rump width

\begin{tabular}{|c|c|c|c|c|c|c|c|c|c|c|}
\hline \multirow[t]{2}{*}{ Trait } & & \multicolumn{9}{|c|}{ Score in points } \\
\hline & & 1 & 2 & 3 & 4 & 5 & 6 & 7 & 8 & 9 \\
\hline \multirow{2}{*}{ Rump angle } & $\mathrm{n}$ & 4 & 73 & 325 & 1086 & 2283 & 947 & 386 & 74 & 15 \\
\hline & $\%$ & 0.08 & 1.41 & 6.26 & 20.91 & 43.96 & 18.24 & 7.43 & 1.42 & 0.29 \\
\hline \multirow[t]{2}{*}{ Rump width } & $\mathrm{n}$ & 12 & 87 & 485 & 668 & 1006 & 1563 & 1016 & 267 & 89 \\
\hline & $\%$ & 0.23 & 1.68 & 9.34 & 12.86 & 19.37 & 30.10 & 19.56 & 5.14 & 1.71 \\
\hline
\end{tabular}

Analysis of the results included in Table 2 shows that human intervention was required for $7 \%$ of calvings, of which dystocia (surgical treatment, injury to the cow or calf, embryotomy) occurred in $0.19 \%$ and caesarean section was performed in $0.11 \%$ of the cases. When analysing the effect of bull's origin on the type of parturition in dairy herds from northeastern Poland, Nogalski et al. (2010) found that difficult parturitions requiring the use of great force and dystocias requiring veterinary assistance represented $15.67 \%(10.26 \%$ and $5.41 \%$, respectively). In another study (Otwinowska-Mindur \& Żarnecki 2005) the proportion of parturitions that required veterinary intervention was $0.68 \%$, while dystocia, caesarean section and embryotomy appliedfor $0.04 \%$ of the cases. It seems that discrepancies observed in the incidence of complicated calvings result from different methods of coding the course of parturition, which needs to be standardized.

The results obtained show that rump angle has an effect on the course of parturition $(P<0.01$, Table 2). It was found that human intervention at calving was required most frequently (8.12-9.84\%) when the scores for rump angle were the highest (8-9 points) and the lowest (1-2 points) and least frequently (5.5\%) for the score of 3 points. Raised rump (1-2 points) was accompanied by the largest (1.09\%) proportion of dystocia (surgical treatment, injury to the cow or calf, embryotomy) and caesarean sections ( $0.55 \%)$. No such tendency was observed 
for dystocia and caesarean sections in the cows which scored 8-9 points for rump angle. As the score for rump angle increased beyond 5 points, the proportion of difficult parturitions (requiring much more force than normal) tended to increase from $6.54 \%$ to $8.12 \%$. For the optimum rump angle (5 points), the proportion of difficult parturitions and caesarean sections was low compared to the other classes of this trait. The significant effect of rump angle on calving ease was also reported by Nogalski (2004), who found a lower proportion of dystocia in cows with pelvis sloping towards the rear. Also other authors (De Jong 1991, Wójcik \& Czaja 2003) found that the course of calving is positively affected by sloping rump, but slightly sloping rump is considered to be the most desirable because excessively sloping rump contributes to more frequent vaginal and uterine prolapse (Brzozowski 2002). Dadati et al. (1985) found that from an economic perspective, sloping rump is more favourable than raised rump.

Table 2

Rump angle and the course of parturition in cows

\begin{tabular}{lcccccc}
\hline $\begin{array}{l}\text { Rump angle } \\
\text { score, pts. }\end{array}$ & $\begin{array}{c}\text { Number of } \\
\text { parturitions }\end{array}$ & Unassisted & Easy & Difficult & Dystocia & Caesarean section \\
\hline $1-2$ & 183 & 36.61 & 53.55 & 8.20 & 1.09 & 0.55 \\
3 & 864 & 33.22 & 61.29 & 5.26 & 0.12 & 0.12 \\
4 & 2770 & 29.87 & 63.09 & 6.64 & 0.22 & 0.18 \\
5 & 6058 & 30.90 & 62.24 & 6.54 & 0.23 & 0.08 \\
6 & 2477 & 27.38 & 65.34 & 7.12 & 0.08 & 0.08 \\
7 & 960 & 29.13 & 63.20 & 7.47 & 0.11 & 0.11 \\
$8-9$ & 199 & 26.40 & 65.48 & 8.12 & 0.00 & 0.00 \\
General & 13364 & 30.07 & 62.92 & 6.70 & 0.19 & 0.11 \\
\hline
\end{tabular}

*significant at $P \leq 0.05$

The average score for rump angle was 5.01 points and that for rump width was 5.54 points (Table 3). The results obtained are slightly lower than those reported by Wójcik $(2002,2006)$ (rump angle 5.30-5.42 points, rump width 5.73-5.61 points). This may be due to the decadelong selection of Holstein-Friesian cattle for high, globular udder, extended forward and well backward. The suspensory ligament of the udder is attached to the pelvic symphysis and ischial bone. A long and level rump is conducive to udder extension and its high vulvarabdominal attachment (Nogalski 2004).

Table 3

Scores for rump angle and rump width in cows depending on the course of parturition

\begin{tabular}{lcc}
\hline Course of parturition & Sump angle & Rump width \\
\hline Unassisted & $4.95^{\mathrm{a}}$ & 5.47 \\
Easy & $5.02^{\mathrm{a}}$ & 5.52 \\
Difficult & 5.06 & 5.59 \\
Dystocia & 4.62 & 5.73 \\
Caesarean section & 4.60 & 5.60 \\
General & 5.01 & 5.54 \\
\hline
\end{tabular}

${ }^{a}$ significant at $P \leq 0.05$ 
The average score for rump angle in the case of unassisted and easy calvings was 4.95 and 5.02 points, respectively (corresponding to the most desirable, slightly sloping rump) and 4.6 points in the case of dystocia and caesarean sections (Tab. 3). Studies by De Jong (1991, 1998) demonstrated that a reduction in score for rump angle (raised rump - scores moving towards 1) increases the frequency of difficult parturitions. The relationship between average score for rump angle and the course of calving fully confirm the results presented in Table 2 that the proportion of dystocias and caesarean sections increase with raised rump. Tyczka et al. (1998) found that raised rump results from ischia became elongated and curved upwards, thus reduced pelvic outlet, which may explain the higher frequency of dystocia. Wójcik (2006), who included easy and difficult births in his study, found that easy calving cows had an average rump angle score of 5.36 points and a slightly higher score (5.46 points) was characteristic of cows with difficult calving.

Table 4

Rump width and course of parturition in cows

\begin{tabular}{|c|c|c|c|c|c|c|}
\hline \multirow{2}{*}{$\begin{array}{l}\text { Score for rump } \\
\text { width, pts. }\end{array}$} & \multirow{2}{*}{$\begin{array}{l}\text { Number of } \\
\text { parturition }\end{array}$} & \multicolumn{5}{|c|}{ Proportion, $\%$ of parturitions ( $x 2=26.23$ ) } \\
\hline & & Unassisted & Easy & Difficult & Dystocia & Caesarean section \\
\hline $1-2$ & 244 & 27.46 & 64.75 & 7.38 & 0.41 & 0.00 \\
\hline 3 & 1315 & 36.60 & 59.54 & 5.70 & 0.08 & 0.08 \\
\hline 4 & 1745 & 30.03 & 62.81 & 6.93 & 0.17 & 0.06 \\
\hline 5 & 2595 & 29.71 & 63.47 & 6.44 & 0.23 & 0.15 \\
\hline 6 & 4019 & 29.34 & 63.60 & 6.74 & 0.17 & 0.15 \\
\hline 7 & 2599 & 27.70 & 63.41 & 6.58 & 0.19 & 0.12 \\
\hline 8-9 & 847 & 29.63 & 61.51 & 8.50 & 0.35 & 0.00 \\
\hline General & 13364 & 30.07 & 62.92 & 6.70 & 0.19 & 0.11 \\
\hline
\end{tabular}

The results obtained allow us to confirm the findings of De Jong $(1997,1998)$ that the proportion of difficult parturitions and dystocia was higher in cows with a too narrow rump (score of 1-2 points) compared to the other cows (Tab. 4). In the studied population, also the parturitions of cows whose rump width was scored with 8-9 points, required human intervention slightly more often. Meanwhile, Wójcik \& Czaja (2003) found that the higher the score for rump width, the easier the parturition. However, our statistical analysis failed to show statistically significant correlations between the course of parturition and the score for rump width (Tab. 3 and 4). This may be indicative of the lack of clear criteria for scoring this trait. According to Guliński et al. (2003), the assessment of rump width yields the least objective results and selectors perceived rump conformation differences to a small extent.

Also Wójcik (2006) demonstrated that course of parturition is not significantly related to the score of rump width, but showed a significant relationship with rump width determined based on body measurements. Likewise, Tyczka et al. (1996), Nogalski et al. (2000), Wójcik \& Czaja (2003) and Murray et al. (2002) showed that the course of parturition is determined by pelvic dimensions. Wójcik (2006), who obtained low $(r=0.12$ to 0.29$)$ but statistically insignificant correlations between the score of rump width expressed in points and the score determined from body measurements, shows the need for modifying the scoring system for rump width to standardize the scores for this trait. Further research also appears necessary regarding the correlations between conformation traits, body measurements and the course of parturition. 
In summary it may be stated that out of the rump traits used in the assessment of cows for type and conformation, rump angle has a stronger effect on ease of parturition compared to rump width. The largest proportion of difficult parturitions (over $8 \%$ ) was noted when the calvers received rump angle scores of 1-2 or 8-9 points, while raised rump (1-2 points) increased the proportion of dystocia and caesarean sections. A much higher proportion of difficult parturitions and dystocia was also found in cows with a too narrow rump scored with 1-2 points and in those with a wide rump (8-9 points). The inclusion of rump conformation traits in selection programmes may help to reduce the risk of complicated calvings.

\section{References}

Ali TE, Burnside EB, Schaeffer LR (1984) Relationship Between External Body Measurements and Calving Difficulties in Canadian Holstein-Friesian Cattle. J Dairy Sci 67, 3034-3044

Brzozowski P (2002) Development of evolution of type of conformation of dairy cattle in Poland. Zesz Nauk PTZ 66, 15-31 [in Polish]

Brzozowski P, Kaczmarek A (1988) Relationship between cow and calf body measurements and calving performance. Zesz Probl Post Nauk Rol 333, 185-189 [in Polish]

Dadati E, Kennedy BW, Burnside EB (1985) Relationships Between Conformation and Reproduction in Holstein Cows: Type and Calving Performance. J Dairy Sci 68, 2639-2645

De Jong $G$ (1991) What is the optimal rump angle for the dairy cow. Veepro Mag 11, 20-21

De Jong G (1997) Scoring legs \& feet in the Dutch conformation scoring system. Interbull Bull 15, 130-135

De Jong G (1998) The maternal calving process index. Veepro Mag 31, 8-9

Dematawena CMB, Berger PJ (1997) Effect of Dystocia on Yield, Fertility, and Cow Losses and an Economic Evaluation of Dystocia Scores for Holsteins. J Dairy Sci 80, 754-761

Gaines JD, Peschel D, Kauffman RG, Schaefer DM, Badtram G, Kumi-Diaka J, Clayton MK, Milliken G (1993) Pelvic growth, calf birth weight and dystocia in Holstein $x$ Hereford heifers. Theriogenology 40, 33-41

Guliński P (1998) [The use of linear system in the polish black and white milk cattle type evaluations]. Rozpr Nauk 55, WSR-P Siedlce, 1-67 [in Polish]

Guliński P, Niedziałek G, Młynek K (2003) An attempt to evaluate the linear system efficiency Black-and-White dairy cows' type classification. Zesz Nauk PTZ 68, 345-353 [in Polish]

Hoffman PC (1997) Optimum body size of Holstein replacement heifers. J Anim Sci 75, 836-845

Murray RD, Cartwright TA, Downham DY, Murray MA, De Kruif A (2002) Comparison of External and Internal Pelvic Measurements of Belgian Blue Cattle from Sample Herds in Belgium and the United Kingdom. Reprod Domest Anim 37, 1-7

Nogalski Z (2004) [Factors determining calving ease in Black-and-White heifers and cows]. Rozpr i Monogr 101, UWM Olsztyn, 5-76 [in Polish]

Nogalski Z (2005) [Calving ease as dependent upon pelvic structure in Holstein-Friesian and Jersey heifers]. Rocz Nauk Zoot 22 (Suppl), 579-582 [in Polish]

Nogalski Z, Klupczyński J, Miciński J (2000) [Course of calving, size and viability of calves in relation to cow measurements]. Rocz Nauk Zoot 27, 43-57 [in Polish]

Nogalski Z, Mordas W, Nogalska A (2010) [Effect of the origin of service sires on calving ease in dairy cattle herds in North-Eastern Poland]. Med Weter 66, 566-569 [in Polish]

Otwinowska-Mindur A, Żarnecki A (2005) [Incidence of calving difficulties in Polish Black-and-White cattle]. Rocz Nauk Zoot 22 (Suppl.), 345-348 [in Polish]

Patterson DJ, Herring WO (1997) Pelvic Measurements and Calving Difficulty. Animal Sciences Department, University of Missouri-Columbia, University Extension, Agric Publ G 2017 
Rules for type and conformation assessment of dairy cattle (2004) Inst Zoot Kraków, Poland

Sieber M, Freeman AE, Kelly DH (1989) Effects of Body Measurements and Weight on Calf Size and Calving Difficulty of Holsteins. J Dairy Sci 72, 2402-2410

Thomson DB, Wiltbank JN (1983) Dystocia in relationship to size and shape of pelvic opening in Holstein heifers. Theriogenology 20, 683-693

Tyczka J, Hibner A, Sakowski T, Nowakowski P (1998) [The consequences of improving cow dairy-type rear suspension on the feature lists]. Prz Hod 7, 14-17 [in Polish]

Tyczka J, Hibner A, Tomaszewski A (1996) [Relationship between some conformation traits and characteristics of parturition in Red-and-White first-calf heifers]. Prz Hod 64, 4-8 [in Polish]

Wójcik P (2002) [Selection of dairy cattle based on conformation traits]. Rocz Nauk Zoot 15 (Suppl.), 99-104 [in Polish]

Wójcik P (2006) [Usefulness of body conformation scores and pelvic measurements in selection of cows for easy calving]. Rocz Nauk Zoot, Monogr i Rozpr, Inst Zoot, Kraków, Poland [in Polish]

Wójcik P, Czaja H (2003) [Selection of dairy cattle for rump conformation and calving ease]. Zesz Nauk PTZ 67, 57-65 [in Polish] 